\title{
Pollution influence on bacterial abundance and chlorophyll-a concentration: case study at Idku Lagoon, Egypt*
}

\author{
E. SIAM and M. GHOBRIAL \\ National Institute of Oceanography and Fisheries, Kayed-Bay,. Alexandria, Egypt
}

\begin{abstract}
SUMMARY: Idku lagoon is one of the northern delta lakes, connected with the Mediterranean Sea through Boughaz El Maadyah. It is subjected to industrial, domestic and agricultural pollution. Depending on collected data of water samples during one year of research, the lagoon was separated into different water masses by using the discriminant function analysis (DFA). Estimation of some biological (total and saprophytic bacteria, faecal bacteria and chlorophyll- $a$ ) and chemical variables (chlorosity, organic matter, dissolved oxygen and dissolved inorganic nutrients) lead to differentiate Idku lagoon waters into four sites: Drain (I), Lake Proper (II), Bay (III) and Boughaz (IV). The highly effective parameters for the predicted sites were chlorosity, organic matter and faecal bacteria (E. coli). Factor analysis was applied for each site to find out the correlating variables (biological and chemical) that seemed to control each independent site. At Drain site (I) pollution by agricultural sewage (through Idku Drain) supported bacterial as well as algal growth, while at Lake Proper site (II) bacteria seemed to obtain their nutrient supply from algal origin after their death and lysis. Site II was characterized by its absolute highest chlorophyll- $a$ content. Factor models for sites II and III indicated a positive and mutual relationship between bacterial microbiota and chlorophyll- $a$. The strong correlation that appeared between all biota from factor model for site III, at the absolutely high chlorosity values (compared to the other sites), could be due to the development of salt tolerant strains and species. Factor model for site IV revealed a strong positive correlation between bacterial microbiota and nutrients (derived from industrial pollution at Boughaz El Maadyah), but negatively correlated to chlorophyll- $a$. Thus it seemed that bacteria obtained their nutrient supply mostly from sewage.
\end{abstract}

Key words: Pollution, bacterial population, chlorophyll- $a$, Idku lagoon, Egypt.

\section{INTRODUCTION}

Idku lagoon is the third largest coastal water body in the Nile delta. It is located in the northwestern part of the delta (Fig.1). The lagoon margin is essentially straight along its northern border, the eastern margin is bounded by Idku drain. The only connection of the lagoon with the Mediterranean Sea is the inlet, Boughaz El Maadyah. The depth of

\footnotetext{
*Received September 2, 1998. Accepted May 18, 1999.
}

Idku lagoon ranges from 0.1 to $1.5 \mathrm{~m}$. Lagoon waters are brackish, with fresh discharging mainly from the Idku drain. This large drain, a branch of El Mahmudiya canal, collects drainage water from the Beheirah Province watershed (Saad, 1976).

Sewage and industrial wastes, discharged into the sea from the industrial complex along the Abu Qir coast via El Tabia pumping station, west of El Maadyah, may at times enter the lagoon through the inlet at El Maadyah (Saad, 1978a). The wastes supplement those transported by Idku drain and other 


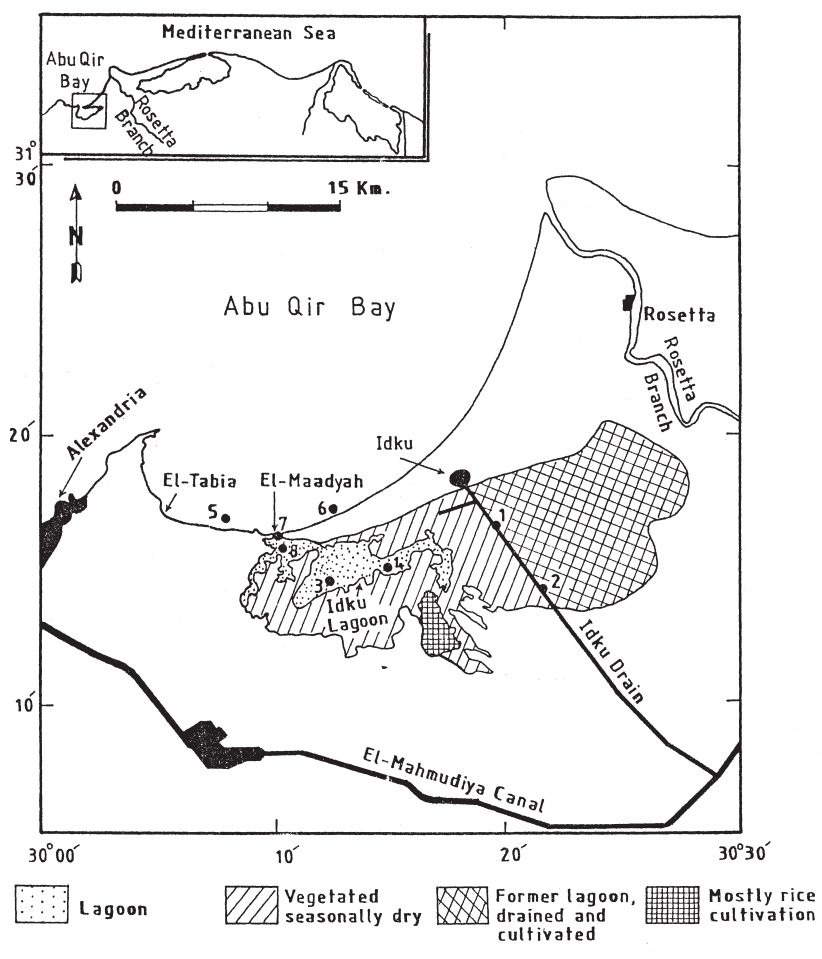

FIG. 1. - Location map of the study area in northwestern Nile delta, showing Idku lagoon and sampling stations (1-8).

channels flowing into the lagoon. Numerous studies have considered the chemical and biological aspects of Idku lagoon (Saad and Ezzat, 1972; Saad, 1976, 1978a, b; Banoub, 1979, 1983).

Idku lagoon is characterized by a marked variation in salinity (Saad, 1978a). This leads to its special feature of well-separated water masses that can often show concomitant phenomena in their biological and chemical characteristics. Domestic, agricultural and industrial sewage contamination of the lagoon water is the most dangerous aspect since it results in high loads of allochtonous organic matter and nutrients, which enhance the growth of microbial mass as well as phytoplankton production. In addition, the introduced sewage may bring high numbers of microorganisms such as the pathogenic coliforms that might threaten aquatic plants and animals and presents also a great hazard of public health.

The purpose of the present study is to discriminate the distinct water masses of Idku lagoon regarding some of their biological and chemical characteristics. The interrelationship between bacteria (represented by total bacterial counts, saprophytes and faecal coliform), chlorophyll-a and some nutrients are investigated.

\section{MATERIALS AND METHODS}

\section{Sample collection}

Four sites were selected to represent the different water quality habitats in Idku lagoon (Fig. 1). Sampling was carried out monthly for one year (June 1995 to May 1996). Two stations were chosen for each site. The four sites were; site (I) Drain, near Idku drain (stations 1 and 2); site (II) Lake Proper, inside Idku lagoon (stations 3 and 4); site (III) Bay, at Abu Qir bay (stations 5 and 6) and site (IV) Boughaz, at Boughaz El Maadyah (stations 7 and 8). Each water sample was divided into two subsamples, one was prefiltered through $56 \mu \mathrm{m}$ pore size for chemical analysis. The other subsample was transported to the laboratory within 2 hours for chlorophyll-a analysis.

\section{Chemical analysis}

The $\mathrm{pH}$ value was determined using a glass electrode $\mathrm{pH}$ meter (ROC $\mathrm{pH}$-meter, Japan). Dissolved oxygen was measured by Winkler standard method (Strickland and Parsons, 1972). The concentrations of dissolved organic matter were estimated as oxygen equivalent, which is proportional to the potassium dichromate (oxidant) consumed (Taras et al., 1974). Dissolved nitrate, nitrite, silicate and chlorosity were determined according to Strickland and Parsons (1972). Dissolved ammonia was determined using indophenol blue method as described by Koroleff (1969). Dissolved phosphate was analysed as molybdate reactive phosphorus (Murphy and Riley, 1962). The previously mentioned physicochemical parameters were estimated by (Gharib and Soliman, 1998). Chlorophyll- $a$ was extracted with methanol and measured spectrophotometrically (Marker et al., 1980).

\section{Bacterial counts}

Water samples were collected from the subsurface layer in sterile screw capped bottles. Total bacterial number was estimated by the acridine orange method according to Hobbie et al. (1977). The saprophytic bacteria were enumerated as colony forming units (c.f.u.) by the pour-plate method using nutrient agar supplemented with salinities $0 \%$, 17.5\%o and 35\%o (Rheinheimer, 1977). Faecal coliforms (E. coli) were detected and enumerated by the five tube fermentation technique (most probable 
TABLE 1. - Mean and seasonal variations in bacterial numbers, chlorophyll-a and chemical parameters recorded at investigated sites in Idku lagoon, Egypt. (n=6 samples, 2x3 $\equiv$ station x month). Site:1, Drain; 2, Lake Proper; 3, Bay and 4, Boughaz; Season: 1, Summer; 2, Autumn; 3, Winter and 4, Spring; TBN: Total bacterial number (cell x 10\% $/ \mathrm{ml}$ ); SB: Saprophytic bacteria (c.f.u./ml); E. coli.: faecal bacteria (col./100ml); Chlor.- $a$ : Chlorophyll- $a\left(\mathrm{mg} / \mathrm{m}^{3}\right)$; SRP: Dissolved phosphate $(\mu \mathrm{g} / \mathrm{l}) ; \mathrm{NH}_{4}$ : Ammonia $(\mu \mathrm{g} / \mathrm{l}) \mathrm{NO}$ : Nitrate $(\mu \mathrm{g} / \mathrm{l}) \mathrm{NO}$ : Nitrite $(\mu \mathrm{g} / \mathrm{l})$; Si: Silicate $(\mathrm{mg} / \mathrm{l})$; DOM: dissolved organic matter $\left(\mathrm{mg} \mathrm{O}_{2} / \mathrm{l}\right)$; DO: Dissolved oxygen $\left(\mathrm{ml} \mathrm{O}_{2} / \mathrm{l}\right)$ and $\mathrm{Cl}$ : $\mathrm{Chlorosity}(\mathrm{g} \mathrm{Cl} / \mathrm{l})$.and \pm standard error of mean.

\begin{tabular}{|c|c|c|c|c|c|c|c|c|c|c|}
\hline Site & \multicolumn{2}{|c|}{ Season } & TBN & \multicolumn{3}{|c|}{$\mathrm{SB}$} & \multicolumn{2}{|c|}{ E. coli } & \multicolumn{2}{|c|}{ Chlor.- $a$} \\
\hline 1 & 1 & & $3.56 \pm .32$ & \multicolumn{3}{|c|}{$8.66 \mathrm{E}+04 \pm 3.98 \mathrm{E}+04$} & \multicolumn{2}{|c|}{$2.01 \mathrm{E}+10 \pm 1.57 \mathrm{E}+10$} & \multicolumn{2}{|c|}{$6.55 \pm 2.49$} \\
\hline 1 & 3 & & $2.91 \pm .25$ & \multicolumn{3}{|c|}{$4.57 \mathrm{E}+03 \pm 2.64 \mathrm{E}+03$} & \multicolumn{2}{|c|}{$1.06 \mathrm{E}+09 \pm 6.85 \mathrm{E}+08$} & \multicolumn{2}{|c|}{$6.52 \pm 1.49$} \\
\hline 1 & 4 & & $1.94 \pm .40$ & \multicolumn{3}{|c|}{$2.45 \mathrm{E}+03 \pm 1.60 \mathrm{E}+03$} & \multicolumn{2}{|c|}{$1.49 \mathrm{E}+07 \pm 1.17 \mathrm{E}+07$} & \multicolumn{2}{|c|}{$8.12 \pm .95$} \\
\hline 2 & 1 & & $6.53 \pm .39$ & \multicolumn{3}{|c|}{$2.04 \mathrm{E}+04 \pm 6.54 \mathrm{E}+03$} & \multicolumn{2}{|c|}{$3.01 \mathrm{E}+05 \pm 2.87 \mathrm{E}+04$} & \multicolumn{2}{|c|}{$54.37 \pm 7.91$} \\
\hline 2 & 2 & & $4.87 \pm .30$ & \multicolumn{3}{|c|}{$6.14 \mathrm{E}+03 \pm 3.32 \mathrm{E}+03$} & \multicolumn{2}{|c|}{$1.18 \mathrm{E}+05 \pm 1.16 \mathrm{E}+05$} & \multicolumn{2}{|c|}{$57.43 \pm 2.17$} \\
\hline 2 & 4 & & $3.52 \pm .17$ & \multicolumn{3}{|c|}{$1.66 \mathrm{E}+04 \pm 6.90 \mathrm{E}+03$} & \multicolumn{2}{|c|}{$1.40 \mathrm{E}+02 \pm 2.03 \mathrm{E}+01$} & $53.45 \pm$ & 12.50 \\
\hline 3 & 1 & & $2.63 \pm .35$ & & $\mathrm{E}+05 \pm 6.38 \mathrm{E}$ & +04 & $1.94 \mathrm{E}+04 \pm 9$ & $.87 \mathrm{E}+03$ & $8.93 \pm$ & 1.27 \\
\hline 3 & 2 & & $1.65 \pm .40$ & & $\mathrm{E}+03 \pm 1.47 \mathrm{E}$ & +03 & $3.10 \mathrm{E}+03 \pm 1$ & $.57 \mathrm{E}+03$ & $8.45 \pm$ & .62 \\
\hline 3 & 3 & & $.56 \pm .18$ & & $\mathrm{E}+03 \pm 7.20 \mathrm{E}$ & +02 & $8.65 \mathrm{E}+02 \pm 3$ & $.73 E+02$ & $4.24 \pm$ & .44 \\
\hline 3 & 4 & & $1.38 \pm .36$ & 5.8 & $\mathrm{E}+02 \pm 2.28 \mathrm{E}$ & +02 & $3.16 \mathrm{E}+03 \pm 1$ & $.05 E+03$ & $2.77 \pm$ & .35 \\
\hline 4 & 1 & & $5.43 \pm .22$ & 5.4 & $\mathrm{E}+05 \pm 4.73 \mathrm{E}$ & +05 & $1.65 E+10 \pm 1$ & $.45 E+10$ & $6.10 \pm$ & 1.48 \\
\hline 4 & 2 & & $4.14 \pm .15$ & & $\mathrm{E}+03 \pm 1.97 \mathrm{E}$ & +03 & $1.25 \mathrm{E}+07 \pm 8$ & $.90 \mathrm{E}+06$ & $7.70 \pm$ & 1.95 \\
\hline 4 & 3 & & $2.72 \pm .44$ & & $\mathrm{E}+03 \pm 3.57 \mathrm{E}$ & +03 & $1.51 \mathrm{E}+07 \pm 1$ & $.38 \mathrm{E}+07$ & $6.40 \pm$ & 2.08 \\
\hline Site & Season & $\mathrm{pH}$ & SRP & $\mathrm{NH}_{4}$ & $\mathrm{NO}_{3}$ & $\mathrm{NO}_{2}$ & $\mathrm{Si}$ & DOM & DO & $\mathrm{Cl}$ \\
\hline 1 & 1 & $7.59 \pm .04$ & $6.34 \pm .73$ & $6.80 \pm 4.19$ & $22.05 \pm 7.01$ & $9.92 \pm 5.97$ & $123.57 \pm 34.73$ & $6.23 \pm .48$ & $1.31 \pm .20$ & $41 \pm 2.89 \mathrm{E}-02$ \\
\hline 1 & 2 & $7.58 \pm 0.7$ & $7.73 \pm .65$ & $1.26 \pm .47$ & $9.03 \pm 4.51$ & $3.89 \pm .88$ & $155.37 \pm 2.97$ & $5.70 \pm 2.45$ & $4.09 \pm 1.42$ & $.48 \pm 4.69 \mathrm{E}-02$ \\
\hline 1 & 3 & $7.64 \pm .15$ & $11.88 \pm .25$ & $11.18 \pm 3.65$ & $33.61 \pm 5.83$ & $15.42 \pm 5.61$ & $152.85 \pm 1.55$ & $9.77 \pm .43$ & $7.45 \pm 1.99$ & $.74 \pm .12$ \\
\hline 1 & 4 & $7.92 \pm .25$ & $6.00 \pm 3.65$ & $17.42 \pm 4.83$ & $39.93 \pm 13.67$ & $18.52 \pm 9.05$ & $129.61 \pm 10.72$ & $5.90 \pm 1.10$ & $3.45 \pm 7.50 \mathrm{E}-02$ & $.48 \pm .12$ \\
\hline 2 & 1 & $8.04 \pm .03$ & $1.74 \pm .25$ & $3.39 \pm 2.51$ & $6.07 \pm 2.16$ & $2.35 \pm 1.24$ & $71.56 \pm 21.27$ & $11.77 \pm 1.97$ & $2.80 \pm .70$ & $1.20 \pm .14$ \\
\hline 2 & 2 & $8.27 \pm .20$ & $1.52 \pm .20$ & $5.63 \pm 1.74$ & $16.80 \pm 6.96$ & $1.79 \pm .33$ & $62.73 \pm 28.19$ & $9.70 \pm 2.50$ & $7.62 \pm 2.75$ & $.98 \pm 9.84 \mathrm{E}-02$ \\
\hline 2 & 3 & $8.58 \pm .29$ & $5.09 \pm .78$ & $5.38 \pm 2.88$ & $7.51 \pm 1.10$ & $2.31 \pm .21$ & $102.89 \pm 38.87$ & $12.23 \pm 2.05$ & $9.28 \pm 2.13$ & $1.14 \pm 8.02 \mathrm{E}-02$ \\
\hline 2 & 4 & $8.38 \pm .08$ & $1.92 \pm .79$ & $14.20 \pm 4.56$ & $6.97 \pm 1.81$ & $2.08 \pm .13$ & $115.05 \pm 29.31$ & $9.02 \pm 1.82$ & $6.44 \pm .21$ & $.70 \pm 1.50 \mathrm{E}-02$ \\
\hline 3 & 1 & $7.85 \pm .07$ & $1.23 \pm .43$ & $3.31 \pm 2.28$ & $13.09 \pm 3.99$ & $4.57 \pm .19$ & $47.77 \pm 24.46$ & $3.20 \pm 1.50$ & $2.11 \pm .30$ & $16.67 \pm 1.79$ \\
\hline 3 & 2 & $8.05 \pm .26$ & $1.57 \pm .47$ & $4.20 \pm 2.48$ & $11.86 \pm 6.80$ & $14.63 \pm 1.61$ & $66.92 \pm 27.59$ & $4.27 \pm 2.70$ & $3.38 \pm .34$ & $16.75 \pm 2.68$ \\
\hline 3 & 3 & $7.56 \pm .29$ & $1.36 \pm .16$ & $3.37 \pm .84$ & $6.64 \pm 1.95$ & $2.25 \pm .44$ & $23.69 \pm 6.29$ & $4.98 \pm .33$ & $5.71 \pm 1.14$ & $20.49 \pm .43$ \\
\hline 3 & 4 & $7.94 \pm .17$ & $1.00 \pm .75$ & $13.42 \pm 4.88$ & $13.05 \pm .16$ & $6.19 \pm 1.05$ & $53.29 \pm 14.32$ & $2.97 \pm .97$ & $3.22 \pm .33$ & $15.34 \pm 2.23$ \\
\hline 4 & 1 & $8.03 \pm .07$ & $4.85 \pm .75$ & $6.70 \pm 2.90$ & $12.44 \pm 1.59$ & $6.38 \pm 1.67$ & $123.85 \pm 34.85$ & $2.87 \pm .33$ & $3.16 \pm .84$ & $1.19 \pm .21$ \\
\hline 4 & 2 & $7.95 \pm .10$ & $2.63 \pm 1.01$ & $3.75 \pm 1.68$ & $16.62 \pm 9.56$ & $11.70 \pm 5.98$ & $125.92 \pm 19.83$ & $6.27 \pm 2.41$ & $6.37 \pm 2.13$ & $6.27 \pm 4.46$ \\
\hline
\end{tabular}

number, MPN) and incubated at $44.5^{\circ} \mathrm{C}$ for $24 \mathrm{~h}$ according to American Public Health Association (1982).

\section{Statistical analyses}

Thirteen chemical and biological parameters were selected and entered into the statistical analyses using the statistical computer package SPSS ${ }^{\circledR}$ for Windows $^{\mathrm{TM}}$, Release 6.0 (Norusis, 1993). It was found that the sum of the determined dissolved nitrate, nitrite and dissolved ammonia (as dissolved inorganic nitrogen, DIN) has better results in the calculations. As a result, the total number of examined variables was reduced to 11 . Discriminant function analysis (DFA) was used to classify Idku lagoon waters into different characterized water masses according to determined variables. R-mode factor analysis (FA) with varimax rotation was applied to identify the interrelationships between chemical and biological parameters within the classified water masses of the lagoon.

\section{RESULTS AND DISCUSSIONS}

According to Forsberg and Ryding (1980), lakes can be grouped into trophic categories concerning bacterial abundance. Oligotrophic waters should contain less than $1.7 \times 10^{6}$ cells $/ \mathrm{ml}$, mesotrophic waters $1.7-6.5 \times 10^{6} \mathrm{cells} / \mathrm{ml}$ and eutrophic waters more than $6.5 \times 10^{6}$ cells $/ \mathrm{ml}$. Thus, the four classified sites of Idku lagoon namely; Drain, Lake Proper, Bay and Boughaz could be considered as mesotrophic waters during the four seasons of the year, except that during three seasons in the Bay site, its water could be, then, categorized as oligotrophic water (Table 1). Following the trophic state index given by Carlson (1977), 
TABLE 2. - Evaluation of discriminant functions for the studied water masses, Idku lagoon, Egypt.

\begin{tabular}{lccccccc}
\hline $\begin{array}{l}\text { Function } \\
\text { No. }\end{array}$ & Eigenvalue & Variance $\%$ & Cumulative $\%$ & $\begin{array}{c}\text { Canonical } \\
\text { Correlation }\end{array}$ & $\begin{array}{c}\text { After } \\
\text { Function }\end{array}$ & $\begin{array}{c}\text { Wilks } \\
\text { Lambda }\end{array}$ & Chi- square \\
\hline 1 & 16.5424 & 64.86 & 64.86 & .9711 & 0 & .0023 & 215.70 \\
2 & 6.7675 & 26.53 & 91.40 & .9334 & 1 & .0403 & 114.00 \\
3 & 2.1944 & 8.60 & 100.00 & .8288 & 2 & .3131 & 41.231 \\
\hline
\end{tabular}

calculated on the basis of chlorophyll-a concentration, the four sites fall in the group of most eutrophicated waters (more than $80 \mu \mathrm{g} / \mathrm{l}$ ).

In the current study, the purpose of using the discriminant function analysis (DFA) is to distinguish between different water sites of Idku lagoon, when some chemical and biological parameters characterize each (Table 1). The application of the direct method of DFA for Idku lagoon data indicated that a significant difference exists between the four studied water masses (sites). The first two discriminant functions accounted for $91.4 \%$ of the difference between these sites (Table 2) and the remaining function provides no additional information.

Figure 2 shows all groups (sites) plotted on the first two functions: function one separates sites II and I from site III while function two separates sites I and IV from sites II and III. Table (3) summarizes the classification results obtained through discrimi- nant analysis. It is found that all examined sites have been correctly classified into 4 groups: Drain (I), Lake Proper (II), Bay (III) and Boughaz (IV), each one has its own characteristics. This table shows that the classification of all sites (I to IV) are perfect (i.e. $100 \%$ assignment efficiency). In order to determine which parameters are most important in distinguishing each site, Table 4 shows that the first function is correlated most highly with chlorosity and organic matter, while the second one is loaded heavily with E. coli, chlorophyll- $a$, nutrient (SRP, Si, DIN) and saprophytes.

\section{Factor analysis}

Factor analysis is separately applied for each site of Idku lagoon, depending on the biological and chemical parameters determined during one year of research.

\section{Canonical Discriminant Functions}

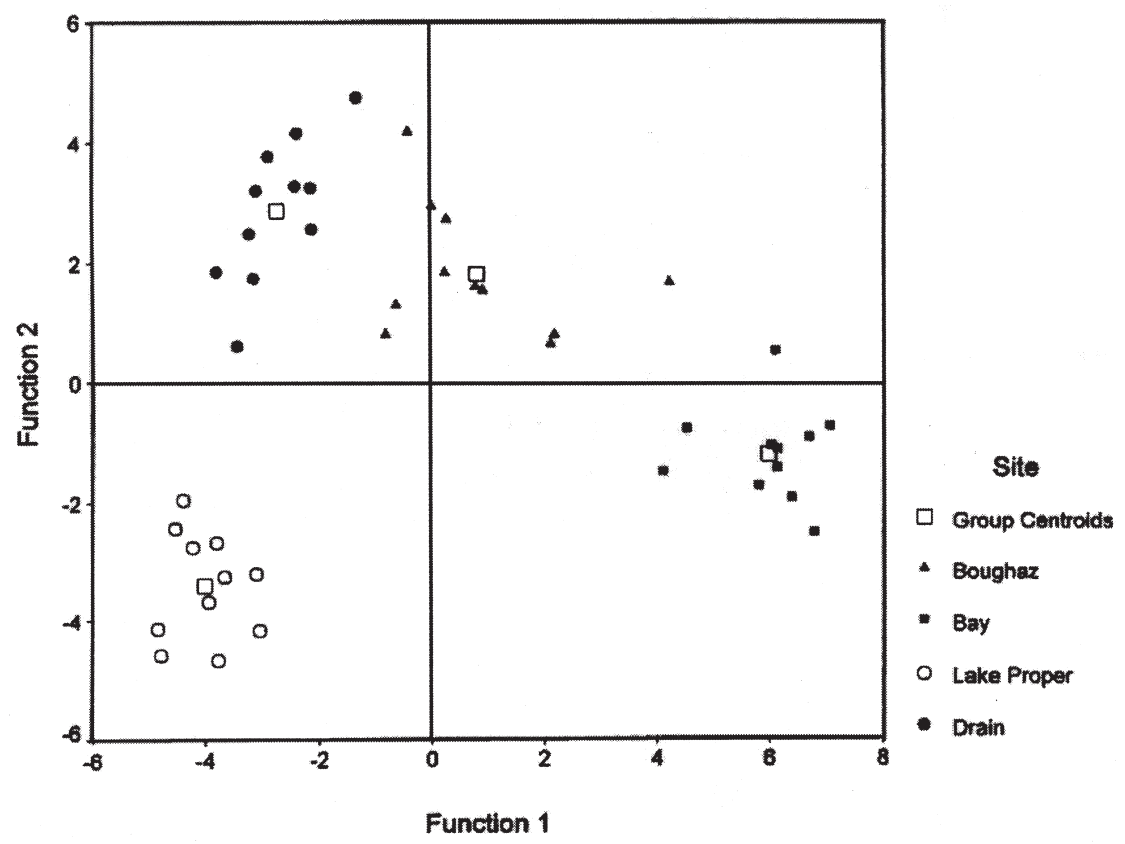

FIG. 2. - Scatterplot of the studied sites on two discriminant functions derived from data matrix, Idku lagoon, Egypt. 
TABLE 3. - Classification results of the studied water masses, Idku lagoon, Egypt.

\begin{tabular}{|c|c|c|c|c|c|}
\hline \multirow[t]{2}{*}{ Actual Group } & \multirow[t]{2}{*}{ No. of samples } & \multicolumn{4}{|c|}{ Predicted Group Membership } \\
\hline & & 1 & 2 & 3 & 4 \\
\hline Group1: Drain (site I) & 11 & $\begin{array}{c}11 \\
100 \%\end{array}$ & $\begin{array}{c}0 \\
0 \%\end{array}$ & $\begin{array}{c}0 \\
0 \%\end{array}$ & $\begin{array}{c}0 \\
0 \%\end{array}$ \\
\hline Group 2: Lake Proper (site II) & 11 & $\begin{array}{c}0 \\
0 \%\end{array}$ & $\begin{array}{c}11 \\
100 \%\end{array}$ & $\begin{array}{c}0 \\
0 \%\end{array}$ & $\begin{array}{c}0 \\
0 \%\end{array}$ \\
\hline Group 3: Bay (site III) & 11 & $\begin{array}{c}0 \\
0 \%\end{array}$ & $\begin{array}{c}0 \\
0 \%\end{array}$ & $\begin{array}{c}11 \\
100 \%\end{array}$ & $\begin{array}{c}0 \\
0 \%\end{array}$ \\
\hline Group 4: Boughaz (site IV) & 11 & $\begin{array}{c}0 \\
0 \%\end{array}$ & $\begin{array}{c}0 \\
0 \%\end{array}$ & $\begin{array}{c}0 \\
0 \%\end{array}$ & $\begin{array}{c}11 \\
100 \%\end{array}$ \\
\hline
\end{tabular}

TABLE 4. - Pooled within-groups correlation between discriminant functions and discriminating variables ${ }^{\text {a }}$

\begin{tabular}{lccc}
\hline Variables & Function 1 & Function 2 & Function 3 \\
& & & \\
\hline Cl & $.62^{*}$ & -.27 & .19 \\
DOM & $-.16^{*}$ & -.10 & -.00 \\
E. coli & -.17 & $.67^{*}$ & .02 \\
Chlor.- $a$ & -.23 & $.45^{*}$ & .29 \\
SRP & -.15 & $.29^{*}$ & -.01 \\
Si & -.15 & $.25^{*}$ & .16 \\
DIN & -.02 & $.20^{*}$ & .04 \\
SB & -.03 & $.09^{*}$ & .07 \\
PH & -.07 & -.26 & $.39^{*}$ \\
TBN & -.22 & -.00 & $.34^{*}$ \\
DO & -.04 & -.07 & $.20^{*}$ \\
& & & \\
\hline
\end{tabular}

a Variables ordered by absolute size of correlation within function. * Largest absolute correlation between each variable and any discriminant function.

\section{Drain water factor model}

\section{(site I) (Stations 1 and 2 )}

This site is characterized by the lowest chlorosity values throughout the year (Table 1). Drain water is running water due to the continuous agricultural drainage deposition. Three factors are obtained from the factor model of this site (Table 5). Factor 1 (pollution influence/bacteria) is a bipolar factor and accounts for $40.5 \%$ of the data variance. The high positive loading for chlorosity $(\mathrm{Cl})$, dissolved oxygen (DO), dissolved inorganic nitrogen (DIN), dissolved organic matter (DOM) and $\mathrm{pH}$ clearly identify the chemical parameters that influence the water mass of site I. This factor has also high negative loading for saprophytic bacteria (SB), faecal bacteria $(E$. coli) and total bacterial number (TBN). Factor 1 reflects sewage pollution by DOM and DIN probably derived from agricultural drainage (Idku drain), which might contain huge amounts of pesticides probably had a lethal effect on the bacterial assemblage.
The correlation between all kinds of bacteria was regarded by Hassan (1993) that bacterial counts of all types were found to correlate generally with each other at the same sampling site and generally during the same season. This is supported by the results of the present investigation as shown in Table 1, which indicated that all estimates of bacterial number showed the same tendency. Thus, they sustained their maximum counts during summer, then their counts tended to decrease gradually during autumn and winter, recording their minima during spring. This tendency was noticed only at sites I and IV.

Factor 2 (nutrient) accounts for $19.7 \%$ of the data variance and shows high positive loading for dissolved phosphate (SRP), TBN and DOM and a negative loading of pH. Spencer (1978) postulated that, in a multi-lake study, a weak, but significant correlation existed between bacterial numbers and orthophosphate uptake. Phosphate loading indicates that continuous supply existed through sewage pollution so that it exceeded bacterial and algal requirements.

TABLE 5. - Varimax rotated factor loading of the Drain water model (site I).

\begin{tabular}{lccc}
\hline Variables & \multicolumn{3}{c}{ Rotated factors } \\
& 1 & 2 & 3 \\
\hline Cl & .92 & & \\
SB & -.98 & & \\
E. coli & -.75 & & \\
DO & .70 & & \\
DIN & .52 & .91 & .47 \\
SRP & & .74 & .90 \\
TBN & -.59 & .54 & -.82 \\
pH & .49 & & 15.5 \\
DOM & .50 & & \\
Chlor.- $a$ & & & \\
Si & & 19.7 & \\
Variance $\%$ & 40.5 & & \\
\hline Loadings less than .40 are omitted.
\end{tabular}


Factor 3 (phytoplankton / nutrient) accounts for $15.5 \%$ of the data variance, with positive loading for chlorophyll-a (Chlor.- $a$ ) and $\mathrm{pH}$ and negative loading of silicate $(\mathrm{Si})$. This leads to suggest the dominance of diatoms, the main consumer of silicate, which showed the highest concentrations overall the other sites and during all seasons indicating, thus, water pollution by silicate derived from agricultural lands.

Drain water model (site I) revealed the dependence of all estimated biota on nutrients (nitrogen, phosphorus, and dissolved organic matter) supply mainly from sewage sources which appeared to enhance their growth.

\section{Lake Proper water factor model \\ (site II) (stations 3 and 4)}

This site is characterized by low chlorosity values, which did not exceed $1.2 \mathrm{~g} \mathrm{Cl} / \mathrm{l}$ (like site I). The silicate high concentrations were sustained during winter and spring. Chlorophyll- $a$ content attained the absolutely highest values overall the other sites (30-57 $\mu \mathrm{g} / \mathrm{l})$, the minimum of which was sustained during the winter. Bacterial communities recorded the highest counts during summer (Table 1).

Lake Proper water factor model shows that factor 1 (biological/chemical) is a bipolar one and accounts for $40.7 \%$ of the data variance (Table 6). It shows positive loading for $E$. coli, TBN and Chlor.- $a$, and negative loading for $\mathrm{pH}$ and DO. This factor indicates the mutual relationship between bacterial flora and phytoplankton, since the latter could stimulate bacterial growth by releasing extracellular organic compounds. The negative DO loading could be explained by the fact that bacterial degradation of organic matter as well as the high influx of algal detritus might have created oxygen deficiency of the trophic condition which resulted into the negative loading of $\mathrm{pH}$.

Factor 2 (biological / nutrient) accounts for $19.1 \%$ of the data variance and shows high positive loading for SB, DIN and Chlor.- $a$, and negative loading for SRP. Factor 2 confirmed the results as shown in Table 1, for Chlor.-a which sustained their maximum records during summer, autumn and spring phytoplankton bloom, while the SRP concentrations were at minimum.

Factor 3 accounts for $15.2 \%$ of the data variance and shows high positive loading of $\mathrm{Cl}$ and DIN, and negative loading of Si. Factor 4 accounts for $9.5 \%$ of the data variance with strong positive loading for
TABLE 6. - Varimax rotated factor loading of the Lake Proper water model (site II).

\begin{tabular}{|c|c|c|c|c|}
\hline \multirow[t]{2}{*}{ Variables } & \multicolumn{4}{|c|}{ Rotated factors } \\
\hline & 1 & 2 & 3 & 4 \\
\hline E. coli & .93 & & & \\
\hline TBN & .91 & & & \\
\hline $\mathrm{pH}$ & -.88 & & & \\
\hline $\mathrm{DO}$ & -.86 & & & \\
\hline SRP & & -.80 & & \\
\hline SB & & .70 & & \\
\hline DIN & & .64 & .59 & \\
\hline Chlor.- $a$ & .45 & .62 & & \\
\hline $\mathrm{Si}$ & & & -88 & \\
\hline $\mathrm{Cl}$ & & & .71 & \\
\hline DOM & & & & .97 \\
\hline Variance $\%$ & 40.7 & 19.1 & 15.2 & 9.5 \\
\hline
\end{tabular}

DOM. The two latter factors indicate pollution derived probably from the cultivated land surrounding the lagoon. It should be noted that, sewage contamination might have enhanced phytoplankton growth which, upon their death and lysis, create eutrophic conditions and consequently stimulate bacterial abundance. Gajewski and Chróst (1995) estimated that up to $48 \%$ of photosynthetically produced organic matter passed through bacterial metabolism in lakes.

Generally, factor model of site II indicates that bacterial growth was supported by phytoplankton exudates in addition to allochtonous sources, while the high loading of E. coli reflects domestic sewage input in this site.

\section{Bay water factor model}

(site III) (stations 5 and 6)

This site recorded the absolutely highest chlorosity values among the other sites (more than $15 \mathrm{~g} \mathrm{Cl} / \mathrm{l}$ ), and the absolutely lowest silicate values (Table 1). The pollution indicator pathogen $(E$. coli) as well as TBN had considerably lower counts than those recorded in the other sites during all seasons. It should be taken into consideration that site III water is brackish (Fig. 1) as such area (seawater) is highly subjected to sewage contamination. Therefore bacterial microbiota, TBN and E. coli, were markedly reduced. It is suggested also that other bacteria types that were better adapted to this environment might have replaced allochtonous bacteria derived from pollution. This is supported 
TABLE 7. - Varimax rotated factor loading of the Bay water model (site III).

\begin{tabular}{lccc}
\hline Variables & \multicolumn{3}{c}{ Rotated factors } \\
& & 2 & 3 \\
\hline DO & -.93 & & \\
E.coli & .85 & & \\
TBN & .80 & & \\
Chlor.- $a$ & .79 & & \\
SB & .70 & .96 & \\
Si & & -.89 & \\
Cl & -.40 & .83 & .47 \\
SRP & & .76 & .94 \\
DIN & & & .40 \\
DOM & & & 13.3 \\
pH & & 24.8 & \\
Variance $\%$ & 39.2 &
\end{tabular}

Loadings less than .40 are omitted.

by Rheinheimer (1987) investigations that, sewage bacteria mostly die rapidly in the brackish water and halophylic forms replace them. The same author postulated also that the active saprophytic bacteria increases faster than the total bacterial number, regarding the saprophytic bacteria as a zymogenous population, i.e., they have the ability to grow on a wide spectrum of organic materials and salinity. This may explain the maintenance of saprophytic bacteria high counts in site III during summer relative to sites I and II.

The results of factor analysis (Table 7) showed that factor 1 (biological) accounts for $39.2 \%$ of the data variance with strong positive loading for $E$. coli, TBN, Chlor.- $a$ and SB. These are negatively correlated with $\mathrm{Cl}$. The biota correlation lead to suggest that they behave not as competitors but rather enjoy mutualist relationship. Factor 1 thus supports the association between bacterial counts and chlorophyll- $a$ as Aizaki et al. (1981) noticed a strong statistical relationship between them in lakes. In addition, Bird and Kalff (1984) admitted that bacteria and phytoplankton are apparently quantitatively tightly linked in lakes. Chlorosity weakly contributes to factor 1 .

Factor 2 (nutrients) accounts for $24.8 \%$ of the data variance, with high positive loading for $\mathrm{Si}$, SRP and DIN and negative loading of $\mathrm{Cl}$. Nutrients in this site appeared to be mostly derived from sewage water, which could support all biota food requirements. Factor 3 accounts for $13.3 \%$ of the data variance with positive loading of SB and DIN, and negative loading for DOM. It is suggested that SB in this site are considered salt tolerant as stated by Hassan (1993) which probably could be responsible for DOM degradation.

From the factor model of site III it could be concluded that all biota whether bacteria or phytoplankton communities might have strains or species which were susceptible to pollution. In addition, chlorosity high values probably enhanced the appearance of the susceptible communities.

\section{Boughaz water factor model \\ (site IV) (stations 7 and 8)}

The chlorosity values ranged between 1.19 and about $6.3 \mathrm{~g} \mathrm{Cl} / 1$. This site is characterized by considerably high silicate contents. Boughaz water factor model shows that factor 1 (bacterial / chemical) accounts for $36.9 \%$ of the data variance (Table 8). It shows positive high loading for SB, E. coli and $\mathrm{TBN}$, and negative loading for DO, DOM and $\mathrm{Cl}$. Hassan (1993) mentioned that faecal coliforms correlate with other bacterial groups. High numbers of the different estimated bacteria were introduced with domestic sewage into this site, particulary during summer (Table 1). The bacterial populations play an important role in the turnover of DOM (Rheinheimer, 1977).

Factor 2 (nutrient / biological), accounts for $24 \%$ of the data variance. It shows positive loading for SRP, DIN, Si and DO, and negative loading for Chlor.- $a$ and $\mathrm{Cl}$. Inorganic nutrients possibly due to sewage outfalls. Negative loading of chlor.- $a$ might due to water salinity. Factor 3 accounts for $11.9 \%$ of the data variance and shows positive loading for $\mathrm{pH}$ and $\mathrm{Si}$, and negative loading for TBN.

TABLE 8. - Varimax rotated factor loading of the Boughaz water model (site IV).

\begin{tabular}{lccc}
\hline Variables & \multicolumn{3}{c}{ Rotated factors } \\
& 1 & 2 & 3 \\
\hline SB & .88 & & \\
E.coli & .87 & & -.62 \\
TBN & .68 & .51 & \\
DO & -.67 & & \\
DOM & -.53 & .85 & .76 \\
SRP & & -.72 & .64 \\
Chlor.- $a$ & & .59 & .96 \\
Cl & -.58 & & 11.9 \\
DIN & & & \\
Si & & 24.0 & \\
pH & & & \\
Variance $\%$ & 36.9 & &
\end{tabular}


Factor model of site IV might reveal water pollution through the introduction of indicator bacteria and inorganic nutrients.

Generally the low records of SB, TBN and Chlor.- $a$ could be due to that these biota are controlled by climatic changes which act through physical and chemical parameters and also through other biological components of the ecosystem (zooplankton). The processes of grazing, predation, antibiosis, autoinhibition, competition between bacterial species and self-purification capacity might be responsible for their low values although the availability of food support through continuous sewage outfalls.

In conclusion, Idku lagoon is subjected to natural processes of eutrophication accelerated by human activities. Domestic, agricultural sewage and industrial contamination of lagoon water are the most dangerous aspects. Consequently high load of allochtonous organic matter and nutrients which might seriously contaminate the natural habitat. The lagoon was differentiated into four sites describing well-characterized water masses.

The four predicted sites showed sometimes common properties while other times they exhibited differentiation in their biological and chemical characteristics. Thus, Drain (I) and Boughaz (IV) sites indicated heavily faecal pollution, while saprophytic counts and total bacterial numbers recorded their maxima during summer at all four sites. Lake Proper site (II) sustained the absolutely highest chlorophyll-a concentration records. As for nutrients, silicate represented absolute high values at the Drain site (I) and to a lesser extent at Boughaz site (IV). Chlorosity recorded the highest values at the Bay site (III).

Factor models for the four sites of Idku lagoon indicated allochtonous pollution which seemed to favour bacterial growth, at all sites, while it highly enhanced phytoplankton growth at Lake Proper site.

\section{REFERENCES}

Aizaki M., A. Otsuki, T. Fukushima, M. Hosomi. and K. Muraoka. - 1981. Application of Carlson's trophic state index to Japanese lakes and relationships between the index and other parameters. Verh. Int. Verein. Limnol. 21: 675-681.

American Public Health Association. - 1982. Standard methods for examination of water and wastewater. Publ. APHA Inc., N.Y., $16^{\text {th }}$ ed, USA.

Banoub, M.W. - 1979. The salt regime of Lake Idku (Egypt) before and after the construction of Aswan's high dam. Arch. Hydrobiol. 83: 392-399.

Banoub, M.W. - 1983. Nutrient salts of Idku (Egypt) before and after the Aswan high dam. (1958-1969). Rapp. Comm. Int. Mer. Médit. 28: 181-183.

Bird, D.F. and J. Kalff. - 1984. Empirical Relationships between Bacterial Abundance and Chlorophyll Concentration in Fresh and Marine Waters. Can. J. Fish. Aquat. Sci. 41: 1015-1023.

Carlson, R.E.. - 1977. A trophic state index for lakes. Limnol. Oceanogr. 22: 361-369.

Forsberg, C. and S.O. Ryding. - 1980. Eutrophication parameters and trophic state indices in 30 Swedish waste-receiving lakes. Arch. Hydrobiol. 89: 189-207.

Gharib, S.M. and Soliman, A.M. - 1998. Some water characteristics and phyto-zooplankton relationship in lake Edku (Egypt) and adjacent sea. Bull.Fac. Sci. Alex. Univ., 38 (1,2): 25-44.

Gajewski, A.J. and R.J. Chr st. - 1995. Microbial enzyme activities and phytoplankton and bacterial production in the pelagical of the great Mazurian lakes (North-eastern Poland) during summer stratification. Ekologia Polska. 43: 245-265.

Hassan, E.S. - 1993. Monitoring of microbial water quality and saprophytic bacterial genera of the Abu Dhabi coastal area, U.A.E. Mar. Biol. 116: 489-495.

Hobbie, J.E., R.J. Daley and S. Jasper. - 1977. Use of Nucleopore filters for counting bacteria by fluorescence microscopy. Appl. Environ. Microbiol. 33: 1225-1228.

Koroleff, F. - 1969. Determination of ammonia as indophenol blue. Intern. Councel for Exploration of the Sea (ICES), C.M., 1969/ C: 8 (mimeo).

Marker, A.F.H., C.A. Crowther and R.J.M. Gunn. - 1980. Methanol and acetone as solvents for estimating chlorophyll and phaeopigments by spectrophotometry. Arch. Hydrobiol. Beih. Ergebn. Limnol. 14: 52-69.

Murphy, J. and J. P. Riley. - 1962. A modified single solution method for the determination of phosphate in natural waters. Analitica Chimica Acta, 27: 31-36.

Norusis, M.J. - 1993. SPSS for Windows: Base system User's Guide, Release 6.0, SPSS Inc., 828 p.

Rheinheimer, G. - 1977. Regional and seasonal distribution of saprophytic and coliform bacteria. In: G. Rheinheimer (ed.), Microbial ecology of a brackish- water environment. Ecol. 10: 243-255.

Rheinheimer, G. - 1987. Relations between pollution and bacterial flora in the western Baltic. Proceedings of the symposium of the Baltic Marine Biologists. Publ. Sea Fish. Inst., Gdynia, 33-39.

Saad, M.A.H. - 1976. Some limnological investigations of lake Idku, Egypt. Arch. Hydrobiol. 77: 411-430.

Saad, M.A.H.. - 1978a. A study on the mixed waters between Lake Idku and the Mediterranean Sea. Bull. Off. Natl. Pêch. Tunisie 2: 347-354.

Saad, M.A.H. - 1978b. Distribution of phosphate, nitrite and silicate in Lake Idku, Egypt. Verh. Int. Verein. Limnol. 20: 11241130.

Saad, M.A.H. and A. Ezzat. - 1972. The bottom of Lake Idku, Egypt. Rapp. Comm. Int. Mer Médit. 21: 129-132.

Spencer, M.J. - 1978. Microbial and biomass relationships in 26 oligotrophic to mesotrophic lakes in South Island, New Zealand. Verh. Int. Verein. Limnol. 20: 1175-1181.

Strickland, J.D.H. and T.R. Parsons. - 1972. A practical handbook of seawater analysis. Bull. Fish. Res. Board Can. 167: 310 p.

Taras, M.J., A.E. Greenberg, R.D. Hoah and M.C. Rand. - 1974. Standard methods for the examination of water and wastewater. American Public Health Association. Wat. Pollut. Contr. Fed. (WPCF) 13 ed., 1134 p.

Scient. ed.: J.D. Ros 